УДК 378.147: 793.35

DOI: $10.35619 /$ iiu.v1i10.182

Тюска Валентина

кандидат педагогічних наук, доцент, доцент кафедри культурології та музеєзнавства Рівненського державного гуманітарного університету, м. Рівне, Україна ORCID: 0000-000-7088-5698 e-mail:valtyuska@gmail.com

\title{
СТАНОВЛЕННЯ КУЛЬТУРИ МАЙБУТНІХ ПЕДАГОГІВ В УМОВАХ КЛУБНОЇ ДІЯЛЬНОСТІ
}

Анотація. У статті висвітлено можливості клубної діяльності як одного із засобів, що сприяє розвитку культури майбутнього фахівця. Розкрито поняття «культура» та «професійно-педагогічна культура педагога» як основних чинників творчого становлення студентів. У дослідженні зосереджено увагу на формуванні педагогічної культури майбутнього педагога. Презентовано досвід студентського клубу «Дозвілля Soft Skills», який діє при кафедрі культурології та музеєзнавства РДГУ. Розглянуто дозвіллєву діяльність як засіб формування комплексу надпрофесійних навичок Soft Skills за трьома ключовими функціональними напрямами: навички людей, соціальні навички та особисті кар'єрні уміння. Діяльність клубу спрямовується на розвиток у студентів якостей творчої особистості, які роблять їх спроможними до активної участі у навчанні, а в майбутньому - і у професійній діяльності. Зокрема, формується у членів клубу культура мислення, абстрактне, понятійне, творче мислення. Проаналізовано методику організації емоційно-образних ситуацій, ситуацій-інсценізацій. За допомогою інноваційних форм роботи клубу майбутні педагоги оволодівають методами абстрактного мислення, прийомами творчої уяви, інтуїції. Студенти тренують логічне мислення та розвивають пам'ять, уяву, творчу інтуїцію, винахідливість, кмітливість, увагу, майстерність планування та прийняття оптимального рішення в складних ситуаціях. З'ясовано, що сучасні форми роботи збагачують клубну діяльність професійним змістом, сприяють формуванню у студентів готовності до професійної діяльності. Сьогодні використання технологій розвитку надпрофесійних навичок майбутніх педагогів $є$ невід’ємною передумовою діяльності закладів вищої освіти. Упровадження клубної діяльності в освітній процес дозволяє розширити можливості студентів, зокрема, їх рівень педагогічної культури.

Ключові слова: культура особистості, клубна діяльність, студентський клуб, майбутній педагог , професійно-педагогічна культура, професійне становлення.

Постановка проблеми. Незважаючи на значний обсяг наукових праць із культурології в зарубіжній і вітчизняній літературі, тема студентської клубної діяльності починає цікавити науковців лише у кінці XX сторіччя. Каталізатором цього інтересу стала професійна спрямованість мистецьких дисциплін як важливої складової прикладної культурології.

Прикладне значення культурології проявляється в тому, що вона бере участь (разом із психологією, соціологією, педагогікою) у вивченні явищ соціалізації, тобто «входження» людини у певну суспільно-культурну систему. У нашому дослідженні такою системою $є$ клуб як засіб впливу на культуру особистості.

Поняття «культура» часто вживається для позначення рівня вихованості й освіченості людини, рівня оволодіння нею тією чи іншою сферою знання або діяльності. У поведінці людей можна спостерігати індивідуальні культурні відмінності. Вони приймають і поділяють цінності, уявлення та поведінку, які 
складають у цілому їхню культуру. У культурології під культурою розуміють сукупність позагенетичних засобів, моделей поведінки, що слугують для зв'язку людської спільноти 3 оточенням. Найсуттєвішими вважаються культурні явища, що сприяють адаптації людини до оточення (Погорілий, 2003 , с. 7). Саме культура, здобуваючи форму активної людської діяльності, сприяє розвитку особистості. Ми поділяємо думку В. Тернопільської (2008, с. 13) , що головна мета культури формування певного типу особистості.

Окреслене розуміння взаємозв'язку культури і діяльності дозволяє в аспекті нашого дослідження розглядати культуру та клубну діяльність як чинники, що впливають на розвиток особистості майбутнього педагога. Оскільки розвиток професійної спрямованості здобувачів вищої освіти полягає в розгортанні потреби та підвищенні їхнього рівня професійної діяльності, то під час правильної організації освітнього процесу на кожному етапі діяльності студентів слід передбачати багатогранну, змінену потребу особистості. Іноді мотив, спочатку пов'язаний $з$ метою діяльності, зміщується на ії засоби з подальшим утворенням нових за змістом мотивів. В інших випадках розвиток потреби обумовлений самим процесом засвоєння нових форм діяльності, оволодіння готовими предметами культури (Швидкий, 2010, с. 130).

Такою формою професійної діяльності здобувачів вищої освіти у нашому дослідженні $€$ клубна робота, яка $є$ засобом впливу на культуру майбутнього педагога, що сприяє формуванню професійної спрямованості та мотивації. Ми зосередили увагу на клубній діяльності студента педагога та його професійній культурі.

Професійно-педагогічна культура - це міра і спосіб творчої самореалізації особистості педагога професійної школи у різноманітних видах педагогічної діяльності і спілкування, спрямованих на засвоєння, передачу і створення педагогічних цінностей та технологій (Жигірь, 2012, с. 197). Професійно-педагогічна культура відображає світогляд вчителя, елементи його загальної культури в галузі професійної творчої діяльності, яка виступає підгрунтям професійної культури вчителя, оскільки не лише вдосконалює педагогічну діяльність, а й $€$ iї сутнісною ознакою. Це обумовлюється необхідністю постійно вирішувати нестандартні за своєю природою педагогічні завдання, визначати їх суперечності, добирати форми, методи педагогічного впливу, ставлення.

Творчо-естетичне ставлення формується на основі емоційно-образної психічної діяльності, яка полягає у миттєвому цілісному оформленні інформації, іiї емоційному сприйманні та оцінці. Це сприяє вдосконаленню функцій свідомості, стимулює творчу активність, евристичну діяльність, прагнення до нового, пошук шляхів виходу за межі вже відомого. Творчий потенціал відображає емоційний досвід, а естетична культура його розвиває та поглиблює, робить почуття яскравішими. Своєю чергою, естетичні почуття та емоційні переживання збуджують роботу думки, стимулюють творчу інтелектуальну діяльність. Естетична розвиненість впливає і на вольові можливості, працездатність, цілеспрямованість. Науковці зазначають, що в основі психофізіологічних механізмів творчого розвитку особистості лежить естетичне, емоційне ставлення до світу, до навчальних завдань та об'єктів зображення, що визначає активність сприйняття та уяви. Ці якості взаємопов'язані 3 творчими здібностями і мають безпосереднє відношення до формування в майбутніх педагогів професійно-педагогічної культури та розвитку культури в цілому.

Аналіз останніх досліджень 3 проблеми. Проблеми розвитку культури майбутніх фахівців, зокрема у клубній діяльності, були і залишаються об'єктом уваги багатьох вітчизняних та зарубіжних дослідників. Вивчали особливості культури особистості у філософсько-методологічних підходах (Е. Кант, Т. Карвер, П. Сорокіна, Е. Тейлор, I. Томас), у культурологічній практиці (М. Аріарський, А. Жарков, Л. Жаркова, В. Кірсанов, I. Петрова, В. Піча); педагогічної культури (Л. Нечипоренко, В. Гринькова, М. Згурська, I. Ісаєв), проблеми, пов'язані із професійною освітою 
(С. Сисоєва, О. Дубасенюк, Н. Ничкало, В. Жигірь, О. Чернєга), клубну діяльність (О. Воловик, В. Гагін, А. Каргін, У. Миронюк, Є. Соколов, С. Смірнова, В. Тріодін).

Мета статті: розкрити можливості клубу як одного із засобів, що сприяє розвитку культури студентів. Домінантним завданням сучасної вищої освіти є забезпечення безперервної аудиторної та позааудиторної виховної роботи, що потребує упровадження спеціальної професійної підготовки майбутніх педагогів.

Виклад основного матеріалу дослідження. Система професійних якостей, або професійна культура фахівця, переважно реалізується у його трудовій діяльності. Система його моральних якостей, або моральна культура спеціаліста, реалізується у багатообразних процесах спілкування і поведінки як у самому колективі, так і поза ним, включаючи естетичні якості (естетичну культуру), реалізуючись у формах естетично-творчої діяльності.

Моральна культура спілкування вчителя завжди є показником того, як, яким чином, за допомогою яких рішень, конкретних педагогічних завдань, методів взаємостосунків педагогу вдається реалізувати соціально вагомі принципи навчання і виховання. Чим ширший творчий діапазон використаних учителем прийомів і засобів успішного спілкування у вирішенні поставлених перед ним завдань, тим вищий рівень його культури. Говорячи про профільну культуру спілкування вчителя, ми перш за все повинні бачити у всіх взаємостосунках уміння досягти поставленої мети навчання і виховання. Тому ми відштовхувалися від того, що клубна діяльність майбутніх педагогів - одна із базисних складових системи самоформування вчителя, оскільки для багатьох студентів клубний колектив - часто колектив різновіковий та різнопрофільний. У нього зазвичай входять не тільки студенти, а й педагоги, відомі діячі культури, науки, політики. Всі вони поставлені в умови спільної творчої праці, ділового та соціального взаємоставлення на рівних. Опираючись на творчість студентів, стимулюючи їх на заняттях i в позааудиторний час, у клубі розкриваються i цілеспрямовано розвиваються творчі здібності майбутніх педагогів, формується творче ставлення, творчий підхід до будь-якої справи й глибше усвідомлюється професійне покликання.

У нашому дослідженні йдеться про технологію організації виховного процесу в контексті студентського клубу. У творчій, як і у будь-якій іншій педагогічній діяльності, важливу роль відіграє педагогічна техніка - уміння педагога керувати своєю поведінкою (міміка, пантоміма, емоції, настрій, техніка, постановка голосу, дикція) та впливати на дитину, колектив тощо. У такий спосіб удосконалюється зовнішня культура майбутнього педагога, що проявляється в його поставі, одязі, гримі, міміці, пантоміміці, культурі педагогічного спілкування, умінні зацікавити, захопити виступом, доповіддю, інформацією; в культурі мови, техніці мови, самореалізації як саморелаксації тощо. Як відомо, ці уміння та навички формуються у процесі тренування, самостійного вправляння, самотренування тощо. Ефективною умовою для цього є студентське клубне об'єднання.

У дослідженні ми зробили спробу визначити педагогічні цінності студентів на основі самооцінки їхніх професійних можливостей. Оскільки «аксіологічний компонент професійно-педагогічної культури спирається на педагогічні цінності і $€$ показником рівня розвитку педагогічної культури викладача. Суб'єктивне відношення викладача до загальнолюдських культурно-педагогічних цінностей визначається багатством його особистості, спрямованістю професійної діяльності, професійнопедагогічною самосвідомістю, індивідуальним стилем діяльності і відбиває, таким чином, його внутрішній світ» (Жигірь, 2012, с. 111). Це підтверджує те, що виховні форми клубної діяльності професійно спрямовують студентів, сприяють ширшому розкриттю їхніх прагнень (мотивації) до педагогічної творчої діяльності через культурологічний аспект.

Враховуючи те, що «культурологічний підхід до виховання забезпечує кожній молодій людині найкращі психологічні умови для проживання у світовому суспільстві, 
формуючи у них здібність до життєдіяльності» (Щукова, 2000, с. 5), базою для розвитку культури майбутнього педагога став клуб «Дозвілля - Soft Skills» (модератор - доцент В. Тюска), створений у 2018 році при кафедрі культурології та музеєзнавства РДГУ. Метою клубу є вивчення і популяризація інноваційних технологій прикладної культурології в освітньому процесі, формування професійної майстерності, становлення творчої особистості студента як майбутнього фахівця. Дозвіллєва діяльність $\epsilon$ засобом формування комплексу надпрофесійних навичок Soft Skills за трьома ключовими функціональними напрямами: навички людей, соціальні навички та особисті кар'єрні уміння.

Одним із завдань діяльності клубу стало підвищення професійної культури майбутнього педагога та формування готовності до професійної діяльності. Програма студентського клубу підвищує мотивацію студентів, адже на початковому етапі професійної діяльності актуалізується потреба у самоствердженні. Вона проявляється в прагненні молодого спеціаліста отримати суспільне визнання в правильності його професійної діяльності, в бажанні досягнути успіху, у прояві зусиль під час оволодіння інноваційними підходами, педагогічною технологією. Розв'язання цих завдань ми вбачаємо в засвоєнні методики освітньої роботи в школі, виробленні нестандартних підходів до проведення творчих заходів. Основу роботи клубу становить вивчення, популяризація інноваційних технологій в освітньому процесі, педагогічна творчість та становлення творчої особистості студента як майбутнього педагога. Колектив студентського клубу осмислює свою педагогічну діяльність, знаходить шляхи розвитку педагогічної творчості. Тут добре розуміють, що творчість пов'язана з майстерністю, тому вся робота клубу передбачає підвищення іï рівня.

Діяльність клубу різноманітна: це і систематичні навчання з метою розвитку навичок професійної поведінки, комунікативні ігри, психологічний лекторій, семінари, тренінги, КВК, «Брейн-ринги», конкурси, мистецькі заходи тощо.

Висока активність студентів проявлялася тільки в діяльності. Ми передбачали такі форми роботи, які допомагають студентам побачити теорію в дії, використати ії для розв'язання практичних завдань. Однією із таких форм роботи є конкурси, в процесі яких студенти мають можливість розкрити певні аспекти своєї професійної майстерності, перевірити широту педагогічної обізнаності, виявити рівні сформованості умінь творчо виконувати завдання; створюються умови для розвитку таких якостей, як педагогічна спостережливість, педагогічна кмітливість, творчість, організаторські здібності, вміння прогнозувати результати обраних засобів і методів досягнення поставленої мети.

Важливою умовою самореалізації студентів в умовах студентського клубу $\epsilon$ спілкування як специфічна форма творчості. У процесі спілкування відбувається взаємний обмін результатами діяльності: інформацією, соціально-психологічними почуттями тощо. Людина пізнає себе, вдивляючись, як у дзеркало, в іншу людину. У процесі спілкування люди виступають водночас і як об'єкти, і як суб'єкти не тільки пізнання, а й самовиховання.

3 метою реалізації програмних якостей майбутнього фахівця, на заняттях у клубі ми конструювали спеціальні емоційно-образні ситуації - метод педагогічних ситуацій, котрі створюють умови для їх творчого вирішення, викликають інтерес у студентів і формують їхні педагогічні цінності. Емоційна ситуація характеризується насамперед певним психічним станом особистості, який виник у процесі емоційного сприйняття 3 метою відкриття нових вражень і емоційних станів під час розв'язання ситуативних задач у клубній діяльності.

Вирішення емоційно-образної ситуації завжди пов'язане 3 такими творчими компонентами, як розвинене дивергентне мислення, уява, уявлення, асоціативна здатність, уміння комбінувати і варіювати відоме у нових сполученнях. Воно завжди пов'язане із самостійним пошуком, із вибором, імпровізацією і творчістю. Під час розв'язання емоційно-образної ситуації знання й уміння, накопичені у процесі клубної 
діяльності, виступають у двоякій ролі: як засіб і як результат творчого рішення. Наприклад, засобом виступають раніше засвоєні наявні в особистості знання, а результатом $є$ нові, отримані у процесі творчої діяльності знання, уміння, творчий досвід. Емоційно-образна ситуація несе у собі таке навантаження: створює творчий мікроклімат, який налаштовує особистість на творчий процес, спонукає її до пошуку емоційно-образного рішення і забезпечує гуманне ставлення до виконання дії за допомогою вибору необхідних оптимальних методів та прийомів впливу. Основна суть емоційно-образної ситуації полягає у тому, щоб перед студентом ставити проблему вибору засобів i способів вираження своїх почуттів, переживань i думок, які виникають під впливом певної ситуації. Ціннісним зерном емоційно-образної ситуації в клубній діяльності є надбання нових моральних цінностей і емоційного досвіду за допомогою розв'язання створених проблемних завдань.

Наші спостереження підтверджують, що емоційно-образні ситуації у клубній діяльності сприяють формуванню у здобувачів вищої освіти професійних цінностей, впливають на розвиток культури. У майбутнього педагога виникає бажання передати в емоційно-образній формі внутрішнє переживання, емоції та думки, долати внутрішні і зовнішні стереотипи поведінки. Тому змістом цього етапу виступають емоційнообразні проблемні педагогічні ситуації. У них майбутній фахівець випробовує емоційні переживання, у результаті чого формується емоційно-ціннісне ставлення до професійної діяльності.

Висновки та перспективи подальших розвідок. Практичний досвід студентського клубу доводить, що розвитку творчих здібностей майбутнього фахівця сприяють клубні форми роботи як ефективний засіб саморозвитку та соціалізації здобувача вищої освіти. Клубна діяльність виводить на творчу співпрацю, на суб'єктсуб'єктні засоби взаємодії викладача і студента. Результати організаційно-діяльної гри у клубі « Дозвілля - Soft Skills » засвідчують, що вирішення навчально-пізнавальних задач, ситуацій із проблем загальнокультурної, духовно-моральної підготовки забезпечує свідомий вибір студентами духовних цінностей, формує на цій основі стійку, неповторну, індивідуальну систему професійно-ціннісних орієнтацій (на творчість у професійній діяльності, розвиток особистості студента, спілкування 3 дітьми та дорослими, професійне самовдосконалення, самореалізацію, професійне співробітництво, обмін духовними цінностями).

У процесі дослідження становлення культури студентів в умовах клубу доходимо висновку, що заняття у клубі приносять задоволення, допомагають вдосконалювати професійні здібності, підвищувати рівень педагогічної культури. Клуб сприяє професійній адаптації майбутніх педагогів та популяризації творчих талантів, досконалість яких спонукає (вплив на мотиваційну сферу) до творчого самовираження студентську молодь, а в майбутньому - організувати аналогічні форми роботи з метою залучення до них підростаючого покоління.

\section{СПИСОК ВИКОРИСТАНИХ ДЖЕРЕЛ}

Культурологія: навч. посібник. (2003). Упоряд. О. І. Погорілий, М. А. Собацький. Київ: Вид. дім КМ «Академія».

Тернопільська, В. (2008). Соціально - комунікативна культура школяра : иляхи сходження. Монографія. Житомир : ПП «Рута».

Швидкий, В. (2010). Акмеологічні підходи до формування образу Я - професіонала у студентів ВНЗ. Акмеологія в Украӥні : наукове видання. № 1. С. 128 - 134.

Жигірь, В.(2012). Професійна педагогіка : навч. посіб. В. І. Жигірь, О. А. Чернєга; [за ред. М. В. Вачевського]. Київ: Кондор.

Щукова, Н. (2000). Новое воспитание. Москва: Педагогическое общество России. 


\title{
REFERENCES
}

Kulturolohiia: navch. posibnyk (2003). [Cultural Studies: handbook]. Uporiad. O. I. Pohorilyi, M. A. Sobatskyi. Kyiv: Vyd. dim KM “Akademiia”. (in Ukrainian)

Ternopilska, V. (2008). Sotsialno - komunikatyvna kultura shkoliara : shliakhy skhodzhennia [Socio-communicative Culture of Students: Ways of Ascension] : monohrafiia. Zhytomyr : PP "Ruta". (in Ukrainian)

Shvydkyi, V. (2010). Akmeolohichni pidkhody do formuvannia obrazu Ya profesionala $\mathrm{u}$ studentiv VNZ [Acmeological Approaches to Form the Image of "Iprofessional Among University Students]. Akmeolohiia v Ukraini : naukove vydannia. No 1. S. 128 - 134. (in Ukrainian)

Zhyhir, V.(2012). Profesiina pedahohika : navch. posib. [Preofessional Pedagogy: textbook]. V. I. Zhyhir, O. A. Chernieha; [za red. M. V. Vachevskoho]. Kyiv: Kondor. (in Ukrainian)

Shchukova, N. (2000). Novoye vospitaniye [New Education]. Moskva: Pedagogicheskoye obshchestvo Rossii. (in Russian)

\section{FORMATION OF CULTURE IN THE FUTURE TEACHERS IN THE CONTEX OF CLUB ACTIVITY}

\author{
Valentyna Tiuska, \\ Candidate of Pedagogical Sciences, Associate Professor, \\ Associate Professor at the Department of \\ Culture and Museum Studies, \\ Rivne State University for the Humanities, \\ Rivne, Ukraine \\ ORCID: 0000-000-7088-5698 \\ e-mail:valtyuska@gmail.com
}

Abstract. The aim of our research is to outline the potential of the club as a means of contributing to the development of the culture of students.

The basis for the development of the culture of the future teacher was the club "Leisure Soft Skills", formed at the Department of Culture and Museum Studies in RSUH. Its main task is to create the favorable conditions for creative self-realization of students, to form practical skills of the future teachers, to fill the spiritual vacuum of the young generation with the organized cultural content, to promote the students' creative approach to the profession. In order to implement the program qualities of the future specialist we have designed the special emotional and the figurative situations during the club activity - the method of pedagogical situations that makes conditions for their creative solutions, interests students and forms their pedagogical values.

The results of play in the club "Leisure - Soft Skills" indicate that the solving of the educational and cognitive tasks, situations of general cultural, spiritual and moral training provides a conscious choice of spiritual values by students, forms on this basis the sustainable, unique, individual system of vocational valuable orientations (creativity in the professional activity, the development of student's personality, communication with children and adults, professional self-improvement, self-fulfillment, professional cooperation, exchange of the spiritual values). The research concludes that the classes in the club bring pleasure and help to improve the professional skills, to raise the level of the pedagogical culture. The club promotes the professional adaptation of students and creative talents, which encourages students to the creative expression, and to organize the similar forms of work in order to familiarize thereto of rising generation in the future.

Keywords: personal culture, club activity, students' club, future educator, professional and pedagogical culture, professional development.

Стаття надійшла до редакиії 10. 10. 2019 р. 